\title{
Association of Risk Factors with Breast Cancer in Libyan Women
}

\author{
Samira. D. Ameigaal ${ }^{1 *}$, Ahmed. A. Ageel' ${ }^{1 *}$ Mostafa. O. Abdoarahem $^{2}$ \\ ${ }^{1}$ Department of medical laboratory, Higher institute of medical technology/ Bani waleed, Libya \\ ${ }^{2}$ Department of Biotechnology, Science faculty, Azzaytuna university, Tarhona, Libya
}

Received: 15 July 2020/ Accepted: 25 December 2020

Doi: https://doi.org/10.54172/mjsc.v35i3.270

\begin{abstract}
Breast cancer (BC) is the most common cancer among Libyan females. There are many important risk factors for BC in different populations as suggested by epidemiological studies. BC is an etiologically complex disease affected by genetic and other environmental factors, which include gender, age, previous breast cancer, body mass index, menopausal status, postmenopausal hormonal therapy, reproductive factor, alcohol consumption, smoking and breastfeeding. The aim of this study was to investigate if there is an association between risk factors and breast cancer among Libyan females. Data were collected by using questioners for 38 cases with breast cancer from Tripoli Medical Center and 100 controls from March 2016 to February 2017. The results showed that risk of breast cancer was associated with age, the mean ages $( \pm \mathrm{SD})$ of the case and control groups were $46.7 \pm 15.6$ and $38.8 \pm 19.1$ respectively, age at the first birth $(\mathrm{P}=0.036)$, family history with first-degree relative percentage of the cases and control groups were $21 \%$ and $4 \%$ and second-degree relatives were $10.5 \%$ and $13 \%$ respectively with statistical difference $(\mathrm{P}=0.042)$ and menopausal status $(\mathrm{P}=0.002)$. The risk decreased with breastfeeding $(\mathrm{P}=0.033)$. No association was observed between passive smoking $(\mathrm{P}=0.363)$ and the number of pregnancies and births $(\mathrm{P}=0.402)$. Data from this study indicated that there were some factors associated with breast cancer among Libyan females including age, age at the first pregnancy, family history and menopausal status.
\end{abstract}

Keywords: Breast cancer, Risk factors, Libyan female.

\section{INTRODUCTION}

Breast cancer is the most common type of cancers among women; it is caused by a combination of genetic and environmental factors (Zhai et al., 2006). In Libya, breast cancer is also considered the most common cancer among females accounting for $26 \%$ of all female cancers (El Mistiri et al., 2007). It also accounts for $41.5 \%$ in 2012 (Bodalal et al., 2014). As well, two studies that were published recently in the western region of Libya, have stated that breast cancer in females was the most common cancer, representing $23.7 \%$ (Elzouki et al., 2018) and 20.6 $\%$ (of cancer cases Elzouki et al., 2018). Worldwide, breast cancer comprises $22.9 \%$ of all cancers in women (Oldenburg et al., 2007), and more than 1.6 million new cases of BC worldwide have been reported in 2010(Forouzanfar et al., 2011). Most breast cancers were reported to occur in women 100 times more likely than in men (Richie \& Swanson, 2003).

Epidemiological studies have suggested that there is an association between some risk factors with BC including genetic and other factors, such as gender, body mass index, postmenopausal, hormonal therapy, reproductive factor, alcohol consumption, smoking and breastfeeding (Lyytinen et al., 2010; MacMahon, 2006; Richie \& Swanson, 2003; Seitz et al., 2012; Singletary, 2003; Van den 
Brandt et al., 2000). BC risk factors are not well reported in Libya. For this reason, this paper, aimed to study association between $\mathrm{BC}$ and risk factors in Libyan women.

\section{MATERIALS AND METHODS}

Study subjects: The study was carried out from March 2016 to February 2017. BC patients participated from Tripoli Medical Center and control subjects were from different cities of Libya. The study cases included 38 women aged 16 to 77 years with confirmed diagnosis of $\mathrm{BC}$, while 100 women aged 16 to 75 years free of $\mathrm{BC}$ were considered as a control group. All subjects completed an in-person interview that used well-structured an Arabic form questionnaire, taking an account the name, age, age of discovering the disease $\mathrm{BC}$, if they have relatives with breast cancer, family history, smoking, if the patient is premenopausal or postmenopausal, marital status, number of births, age at first pregnancy, breastfeeding and routine doing self-examination or not.

Statistical analysis: Comparisons between groups and risk factors have been evaluated using Pearson chi-square test $(\mathrm{P}=0.05)$. We estimated the association between different factors and the risk of $\mathrm{BC}$ using logistic regression analysis. All statistical analyses have been implemented in SPSS version 19.0 (SPSS, Chicago, IL).

\section{RESULTS}

A total of 138 Libyan women were enrolled in this study, among them 38 were inffected with $\mathrm{BC}$ (cases) and 100 were free of BC (controls). All study subjects completed an in- person interview that used an Arabic form questionnaire to assess and observe risk factors of $\mathrm{BC}$ in both groups. The distribution of suspected risk factors of $\mathrm{BC}$ has also been investigated in case and control groups.

The mean ages of case and control groups were 46.7 and 38.8 respectively with a significant difference $(\mathrm{P}=0.0023)$ between them. $\mathrm{BC}$ in case group according to Age is summarised in figure 1. Ages varied between 16 and 77 years, the most of BC cases about $90 \%$ appeared between 30 to 50 years old, while the highest incidence of $\mathrm{BC}$ appeared between the ages 35 and 45 years old.

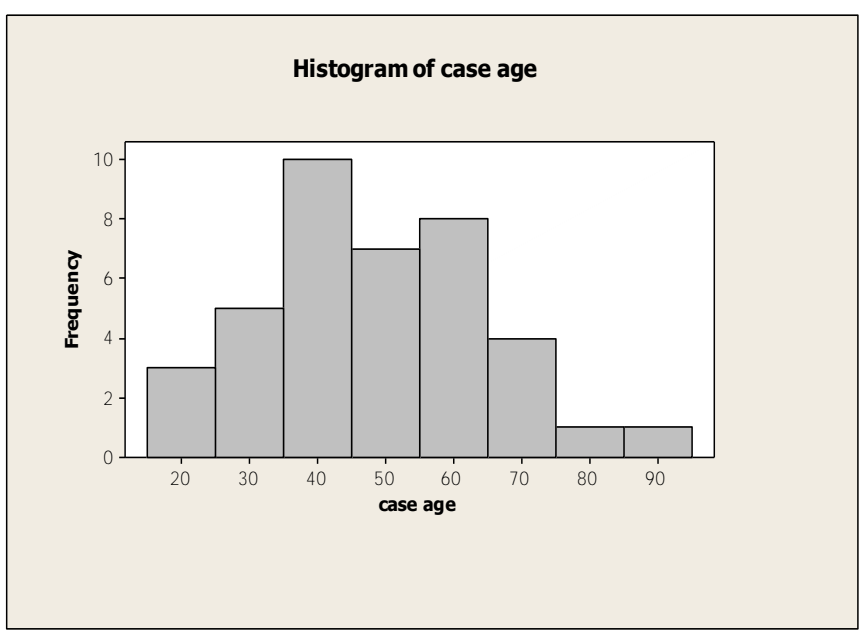

Figure: (1). Histogram of ages of breast cancer cases

Breastfeeding and family history results showed differences between cases and controls. The frequency of breastfeeding in cases was $52.63 \%$ while it was $53 \%$ in the controls $(\mathrm{P}=$ 0.033 ) as illustrated in table 1 . In addition, difference $(\mathrm{P}=0.042)$ between $\mathrm{BC}$ incidence and family history of $\mathrm{BC}$ was found between cases $31.5 \%$ and controls $17 \%$ as shown in table 2 .

Table 1: Analysis of breastfeeding in BC cases and control groups

\begin{tabular}{llll}
\hline \hline $\begin{array}{c}\text { Frequency } \\
\text { of breast } \\
\text { feeding }\end{array}$ & $\begin{array}{c}\text { Cases } \\
\mathrm{n}(\%)\end{array}$ & $\begin{array}{c}\text { Controls } \\
\mathrm{n}(\%)\end{array}$ & P value \\
\hline Yes & 20 & 53 & 0.033 \\
& $(52.6 \%)$ & $(53 \%)$ & \\
No & 18 & 47 & \\
& $(47.4 \%)$ & $(47 \%)$ & \\
\hline \hline
\end{tabular}

Table 2: Analysis of family history in BC case and control groups

\begin{tabular}{llcl}
\hline \hline $\begin{array}{l}\text { Frequency of } \\
\text { family history }\end{array}$ & $\begin{array}{l}\text { Cases } \\
(\%)\end{array}$ & $\begin{array}{l}\text { Controls } \\
\mathrm{n}(\%)\end{array}$ & $\mathrm{P}$ value \\
\hline Yes & 12 & 17 & 0.042 \\
& $(31.6 \%)$ & $(17 \%)$ & \\
No & 26 & 83 & \\
& $(68.4 \%)$ & $(83 \%)$ & \\
\hline \hline
\end{tabular}


The number of women that delivered at their first birth in BC cases was 28 and in controls was 55. Age of women at their first delivery showed statistical difference between the cases and controls with $(\mathrm{P}=0.036)$ as illustrated in table 3 , these results suggested that there was an association between breastfeeding, family history and the ages of women at their first pregnancy and the occurrence of BC in Libyan women. The results demonstrated a significant difference with $(\mathrm{P}=0.002)$ between $\mathrm{BC}$ incidence and menopausal status of $\mathrm{BC}$ between cases and controls as seen in table 4. All remaining factors showed no significant difference between cases and controls as summarized in tables 5 and 6 , passive smoking $(\mathrm{P}=$ $0.363)$, number of pregnancy and births, $(\mathrm{P}=$ 0.402).

Table 3: Analysis of ages of $\mathrm{BC}$ cases and controls at their first birth

\begin{tabular}{lccc}
\hline \hline $\begin{array}{l}\text { Frequency of } \\
\text { ages at first } \\
\text { birth }\end{array}$ & $\begin{array}{l}\text { Cases } \\
(\%)\end{array}$ & $\begin{array}{l}\text { Controls n } \\
(\%)\end{array}$ & P value \\
\hline $15-20$ & $9(32.1 \%)$ & $28(50.9 \%)$ & 0.036 \\
$21-25$ & $14(50 \%)$ & 16 & \\
& $2(7.1 \%)$ & $7(12.7 \%)$ & \\
$26-30$ & 3 & 4 & \\
$31-35$ & $(10.7 \%)$ & $(7.3 \%)$ & \\
\end{tabular}

Table 4: Analysis of menopausal status in BC case and control groups

\begin{tabular}{llll}
\hline \hline $\begin{array}{l}\text { Menopausal } \\
\text { status }\end{array}$ & $\begin{array}{l}\text { Cases } \\
\mathrm{n}(\%)\end{array}$ & $\begin{array}{l}\text { Controls } \\
\mathrm{n}(\%)\end{array}$ & P value \\
\hline Yes & $\begin{array}{c}20 \\
(52.6 \%)\end{array}$ & $\begin{array}{l}25 \\
(25 \%)\end{array}$ & 0.002 \\
& $\begin{array}{l}18 \\
\text { No }\end{array}$ & 75 & \\
& $(47.4 \%)$ & $(75 \%)$ &
\end{tabular}

Table 5: Analysis of passive smoking in BC case and control groups

\begin{tabular}{llll}
\hline \hline $\begin{array}{l}\text { Frequency } \\
\text { of family } \\
\text { history }\end{array}$ & $\begin{array}{l}\text { Cases } \\
\mathrm{n}(\%)\end{array}$ & $\begin{array}{l}\text { Controls } \\
\mathrm{n}(\%)\end{array}$ & P value \\
\hline Yes & $12(31.5 \%)$ & $17(17 \%)$ & 0.042 \\
& & 83 & \\
No & 26 & $83 \%)$ & \\
& $(68.4 \%)$ & $(83 \%)$ & \\
\hline \hline
\end{tabular}

Table 6: Analysis of number of pregnancy and births in $\mathrm{BC}$ case and control groups

\begin{tabular}{lccc}
\hline \hline $\begin{array}{l}\text { Frequency of } \\
\text { number of } \\
\text { pregnancy } \\
\text { and births }\end{array}$ & $\begin{array}{l}\text { Cases } \\
\mathrm{n}(\%)\end{array}$ & $\begin{array}{l}\text { Controls } \\
\mathrm{n}(\%)\end{array}$ & P value \\
\hline $1-6$ & 23 & 33 & 0.402 \\
& $(82.1 \%)$ & $(60 \%)$ & \\
$7-12$ & 5 & 22 & \\
& $(17.9 \%)$ & $(40 \%)$ & \\
\hline \hline
\end{tabular}

The study highlights the importance of early detection and self-examination among Libyan women, as results showed that $34.2 \%$ of cases, discovered the disease by self-examination whereas $65.7 \%$ of patients did not, however, $76 \%$ of control cases did not carry out selfexamination and results showed no significant differences $(\mathrm{P}=0.160)$ as illustrated in table 7 .

Table 7: Analysis of self-examination in $\mathrm{BC}$ cases and control groups

\begin{tabular}{lcc}
\hline \hline $\begin{array}{l}\text { Frequency of self } \\
\text { examination }\end{array}$ & $\begin{array}{c}\text { Cases } \\
\mathrm{n}(\%)\end{array}$ & $\begin{array}{c}\text { Controls } \\
\mathrm{n}(\%)\end{array}$ \\
\hline Yes & $13(34.2 \%)$ & $24(24 \%)$ \\
No & $25(65.8 \%)$ & $76(76 \%)$ \\
\hline \hline
\end{tabular}

\section{DISCUSSION}

The present study has examined the association between the risk factors and BC in Libyan women. Breastfeeding frequencies were significantly different between cases and controls $(\mathrm{P}=0.033)$, suggesting the protective effect of breastfeeding against $\mathrm{BC}$ in Libyan women. Simelar results were reported from Nigeria (Okobia et al., 2005), USA (Stuebe et al., 2009) and Sri Lanka (De Silva et al., 2010). In addition, Helewa suggested that such a protective association might be due to the reduction of endogenous and exogenous carcinogens present in the breast epithelial cells during lactation (Helewa et al., 2002). The current work illustrates that there is an association between $\mathrm{BC}$ and family history in case and control groups $(\mathrm{P}=0.042)$, these findings suggests a positive genetic impact of family history on $\mathrm{BC}$ 
risk in Libyan females. This result is in agreement with previous studies (Phipps et al., 2010; Singletary, 2003).

The results showed differences $(\mathrm{P}=0.036)$ in relation to age at first pregnancy between case and control groups. This outcome is consistent with other epidemiological studies that showed a protective role for the early full-term pregnancy against $\mathrm{BC}$ in developed and industrial countries (Phipps et al., 2010; Soerjomataram et al., 2007).

The findings of the present research work demonstrated that the mean age of patient was 46.7 years and the hieghest percentage was between 35 and 45 age, which implies that risk of $\mathrm{BC}$ increases as age increased. These data are in agreement with earlier report (Ermiah et al., 2012), which revealled that the average age of women affected with BC was 45.4 years as well as other study (Phipps et al., 2010) which indicated that the average age of $\mathrm{BC}$ patient was 48 years in Arab world.

The current study indicated no association $(\mathrm{P}=$ 0.363 ) between $\mathrm{BC}$ and passive smoking. Furthermore, several studies were reviewed (Terry $\&$ Rohan, 2002) and showed an association between smoking and $\mathrm{BC}$, whereas others showed a lack of such association. However, number of smokers amongst Libyan cases and controls were relatively small to be considered for association study.Similarly, the lack of association between number of pregnancies and births among Libyan patients and controls $(\mathrm{P}=0.402)$ was in agreement with other studies in USA (Dietz et al., 1995) and Iran (Mahouri et al., 2007).

The present study has demonstarted that Libyan women who made self-examination were noticeably less than those who did not, since $65.7 \%$ of cases and $76 \%$ of control cases did not carry out the procedure as a prevention measurement. The results indicated lack of public awareness about the importance of early detection among Libyan women. Therefore we argue for immediate effective awareness pro- grams to reduce breast cancer mortality among Libyan women.

The current findings supports the hypothesis that there is association between important risk factors and $\mathrm{BC}$ among the Libyan women and it would be useful to know and understand them to contribute to disease control and prevention. However, the present study faced several limitations including, small number of patients included in comparison to breast cancer percentage among Libyan women. In future studies, we recommend that he sample size should be larger to obtain significant answer about the association between risk factors and breast cancer. Moreover, we encourage assessing other important factors such as genetic factors and considering analysis of DNA mutations from study tissues and blood samples from BC cases. Genetic studies are very valuable to discover the genetic role in breast cancer of the Libyan population.

\section{CONCLUSION}

In conclusion, the present study has indicated that there is an association between the risk of breast cancer and several factors including age, age at the first pregnancy, family history and menopausal status.

\section{ACKNOWLEDGEMENT}

We would like to thank all participants in this study and also we are grateful to students Aisha Abu-hamra, Aisha Salem and Gharam Salama for distributing the questionnaire.

\section{REFERENCES}

Bodalal, Z., Azzuz, R., \& Bendardaf, R. (2014). Cancers in eastern Libya: First results from Benghazi medical center. World journal of gastroenterology: WJG, 20(20), 6293.

Beyased Taha, Firyouz Altrjoman, Nabil Enattah, Farag Eltaib, Nureddin Ashammakhi, Adam Elzaghei (2017). Cancer Incidence in Western Libya: First Results from Tripoli 
Medical Center. Ibnosina J Med BS, 9; (2); 37-45.

De Silva, M., Senarath, U., Gunatilake, M., \& Lokuhetty, D. (2010). Prolonged breastfeeding reduces risk of breast cancer in Sri Lankan women: A casecontrol study. Cancer epidemiology, 34(3), 267-273.

Dietz, A. T., Newcomb, P. A., Storer, B. E., Longnecker, M. P., \& Mittendorf, R. (1995). Multiple births and risk of breast cancer. International journal of cancer, 62(2), 162-164.

El Mistiri, M., Verdecchia, A., Rashid, I., El Sahli, N., El Mangush, M., \& Federico, M. (2007). Cancer incidence in eastern Libya: the first report from the Benghazi Cancer Registry, 2003. International journal of cancer, 120(2), 392-397.

Elzouki, I., Benyasaad, T., Altrjoman, F., Elmarghani, A., Abubaker, K. S., \& Elzagheid, A. (2018). Cancer incidence in western region of Libya: Report of the year 2009 from tripoli pathologybased cancer registry. Libyan Journal of Medical Sciences, 2(2), 45.

Ermiah, E., Abdalla, F., Buhmeida, A., Larbesh, E., Pyrhönen, S., \& Collan, Y. (2012). Diagnosis delay in Libyan female breast cancer. BMC research notes, 5(1), 452.

Forouzanfar, M. H., Foreman, K. J., Delossantos, A. M., Lozano, R., Lopez, A. D., Murray, C. J., \& Naghavi, M. (2011). Breast and cervical cancer in 187 countries between 1980 and 2010: a systematic analysis. The lancet, 378(9801), 1461-1484.

Helewa, M., Levesque, P., Provencher, D., Lea, R. H., Rosolowich, V., \& Shapiro, H.
M. (2002). Breast cancer, pregnancy, and breastfeeding. Journal of obstetrics and gynaecology Canada: JOGC= Journal d'obstetrique et gynecologie du Canada: JOGC, 24(2), 164-180; quiz 181.

Lyytinen, H. K., Dyba, T., Ylikorkala, O., \& Pukkala, E. I. (2010). A case - control study on hormone therapy as a risk factor for breast cancer in Finland: Intrauterine system carries a risk as well. International journal of cancer, 126(2), 483-489.

MacMahon, B. (2006). Epidemiology and the causes of breast cancer. International journal of cancer, 118(10), 2373-2378.

Mahouri, K., Dehghani Zahedani, M., \& Zare, S. (2007). Breast cancer risk factors in south of Islamic Republic of Iran: a case-control study. EMHJ-Eastern Mediterranean Health Journal, 13 (6), 1265-1273, 2007.

Okobia, M. N., Bunker, C., Lee, L., Osime, U., \& Uche, E. (2005). Case-control study of risk factors for breast cancer in Nigerian women: a pilot study. East African medical journal, 82(1).

Oldenburg, R. A., Meijers-Heijboer, H., Cornelisse, C., \& Devilee, P. (2007). Genetic susceptibility for breast cancer: how many more genes to be found? Critical reviews in oncology/hematology, 63(2), 125-149.

Phipps, A. I., Li, C. I., Kerlikowske, K., Barlow, W. E., \& Buist, D. S. (2010). Risk factors for ductal, lobular, and mixed ductal-lobular breast cancer in a screening population. Cancer Epidemiology and Prevention Biomarkers, 19(6), 1643-1654. 
Richie, R. C., \& Swanson, J. O. (2003). Breast cancer: a review of the literature. JOURNAL OF INSURANCE MEDICINE-NEW YORK THEN DENVER--, 35(2), 85-101.

Seitz, H. K., Pelucchi, C., Bagnardi, V., \& Vecchia, C. L. (2012). Epidemiology and pathophysiology of alcohol and breast cancer: Update 2012. Alcohol and alcoholism, 47(3), 204-212.

Singletary, S. E. (2003). Rating the risk factors for breast cancer. Annals of surgery, 237(4), 474.

Soerjomataram, I., Pukkala, E., Brenner, H., \& Coebergh, J. W. W. (2007). On the avoidability of breast cancer in industrialized societies: older mean age at first birth as an indicator of excess breast cancer risk. Breast cancer research and treatment, 111(2), 297302.

Stuebe, A. M., Willett, W. C., Xue, F., \& Michels, K. B. (2009). Lactation and incidence of premenopausal breast cancer: a longitudinal study. Archives of internal medicine, 169(15), 1364-1371.

Terry, P. D., \& Rohan, T. E. (2002). Cigarette smoking and the risk of breast cancer in women: a review of the literature. Cancer Epidemiology and Prevention Biomarkers, 11(10), 953-971.

Van den Brandt, P. A., Spiegelman, D., Yaun, S.-S., Adami, H.-O., Beeson, L., Folsom, A. R., Fraser, G., Goldbohm, R. A., Graham, S., \& Kushi, L. (2000). Pooled analysis of prospective cohort studies on height, weight, and breast cancer risk. American journal of epidemiology, 152(6), 514-527.

Zhai, X., Gao, J., Hu, Z., Tang, J., Qin, J., Wang, S., Wang, X., Jin, G., Liu, J., \&
Chen, W. (2006). Polymorphisms in thymidylate synthase gene and susceptibility to breast cancer in a Chinese population: a case-control analysis. BMc cancer, 6(1), 138. 


\title{
علاقة عوامل خطر الإصابة بسرطان الثي لاى النساء الليبيات
}

\author{
سميرة ضو امعيقل1*، أحمد عبدالعزيز عقيل1، مصطقى عمر عبدالرحيم² \\ 1قسم المختبرات، المعهد العالي للتقنيات الطبية، بني وليد، ليبيا

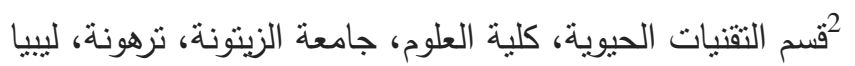

ناريخ الاستلام: 15 يوليو 2020 / ناريخ القبول: 25 ديسمبر 2020 /D3513 https://doi.org/10.54172/mjsc.v35i3.270:Doi

المستلخص : يعتبر سرطان الثدي من أكثر أنواع السرطانات شيوعا بين النساء في ليبيا، وقد أثنتت عدة دراسات سابقة وجود

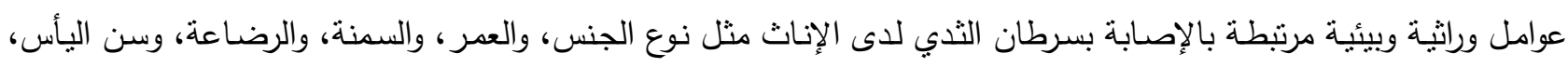
والعلاج الهرموني، والتدخين، وتتاول الكحول. تهذف هذه الدراسة إلى معرفة أهم عوامل خطر الإصابة بسرطان الثذي لثئ لدى النساء الليبيات، حيث تمت دراسة هذه العوامل على 138 مشاركة، 100 منهن غير مصابة بسرطان الثدي (المجموعة الضابطة) و 38 منهن مصابة بسرطان الثذي لمعرفة ارتباط هذه العوامل مـع الإصـابة بسرطان الثدي لدى النساء الليبيات وذلك باستخدام استبيان

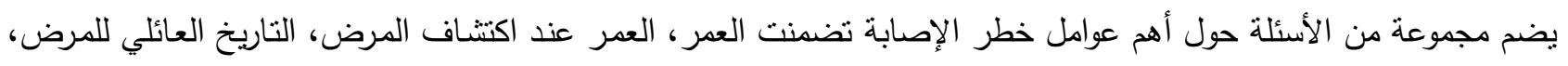

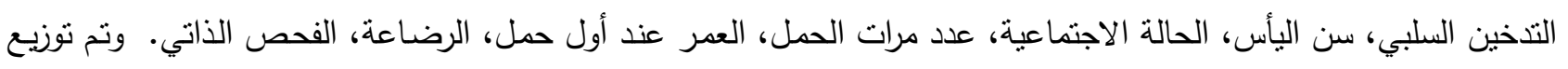
الاستبيان على المشاركات، و تحليل البيانات عن طريق البرنامج الإحصائي SPSS. أظهرت النتائج بأن خطر الإصـابة بسرطان

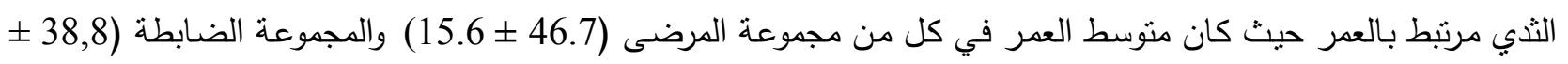

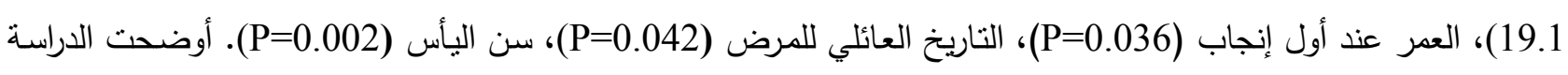
أن معدل خطر الإصابة بسرطان الثذي ينخفض لدى النساء المرضعات (P=0.033)، لم تنتبت الدراسة وجود علاقة بين سرطان الثدي وكل من التدخين السلبي (P=0.363) وعدد مناسبات الحمل والولادة (P=0.402)، عـلاوة على ذلك، وجد أن النسـاء الليبيات تحتاج إلى زيادة في حملات التوعية بأهمية الفحص الذاتي والكثف المبكر وذلك لزيادة فرص النجاة من هذا المرض. نستتج من خلال نتائج هذه الدراسة أن هناك عوامل مرنبطة بالإصابة بسرطان الثني لدى النساء الليبيات وتتشمل كل من العمر ،

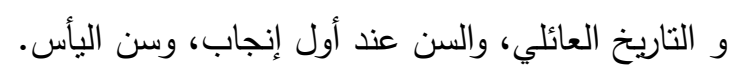
الكلمات المفتاحية : سرطان الثذي، عوامل الخطر، الإناث الليبيات. 